\title{
Media Pembelajaran Berbasis Autoplay Media Studio untuk Siswa SMP
}

\author{
Ian Rizky Maulana ${ }^{1}$, Sapto Adi $^{1}$, Eko Hariyanto ${ }^{1}$ \\ ${ }^{1}$ Pendidikan Olahraga-Universitas Negeri Malang
}

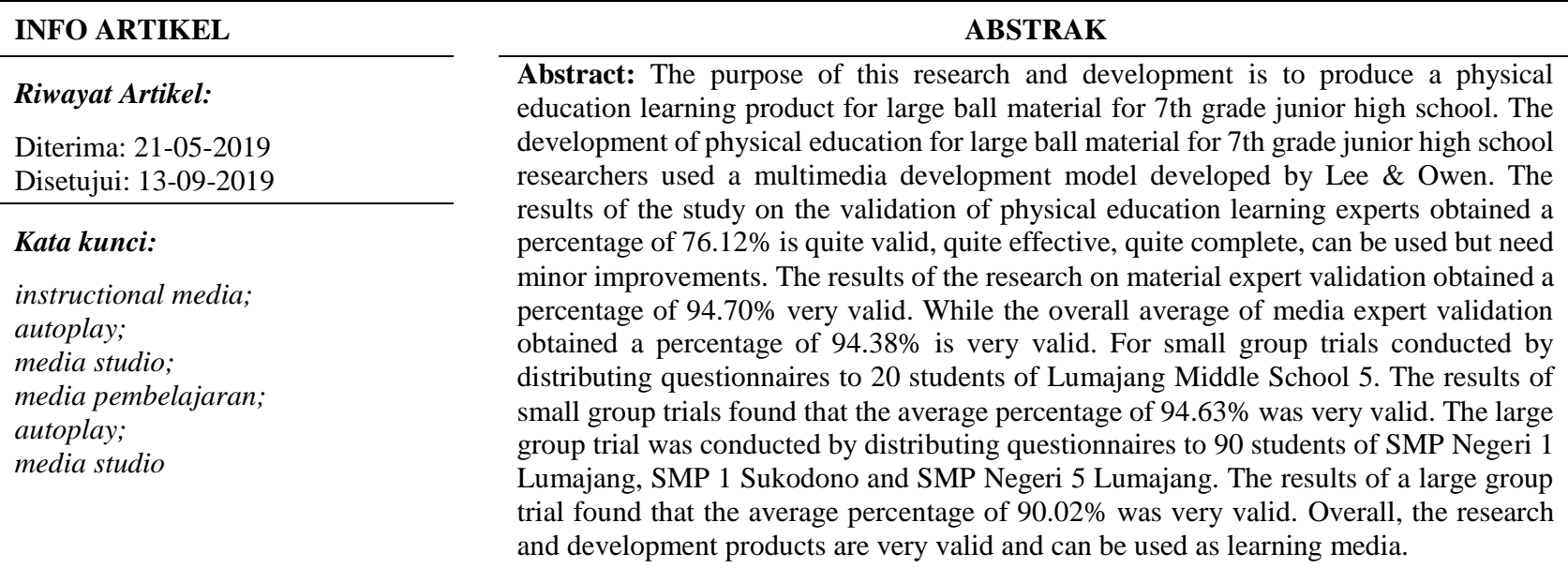

\begin{abstract}
Abstrak: Tujuan penelitian dan pengembangan ini adalah untuk menghasilkan sebuah produk pembelajaran Pendidikan Jasmani materi bola besar untuk SMP kelas VII. Pengembangan pembelajaran Pendidikan Jasmani materi bola besar untuk SMP kelas VII, peneliti menggunakan model pengembangan multimedia yang dikembangkan oleh Lee \& Owen. Hasil penelitian pada validasi ahli pembelajaran Pendidikan Jasmani diperoleh persentase $76,12 \%$ cukup valid, cukup efektif, cukup tuntas, dapat digunakan namun perlu perbaikan kecil. Hasil dari penelitian pada validasi ahli materi diperoleh persentase $94,70 \%$ sangat valid. Rata-rata keseluruhan dari validasi ahli media diperoleh persentase $94,38 \%$ sangat valid. Uji coba kelompok kecil dilakukan dengan penyebaran kuesioner kepada 20 siswa SMP Negeri 5 Lumajang. Hasil dari uji coba kelompok kecil didapat persentase rata-rata sebesar $94,63 \%$ sangat valid. Uji coba kelompok besar dilakukan dengan penyebaran kuesioner kepada 90 siswa SMP Negeri 1 Lumajang, SMP Negeri 1 Sukodono dan SMP Negeri 5 Lumajang. Hasil dari uji coba kelompok besar didapat persentase rata-rata sebesar 90,02\% sangat valid. Secara keseluruhan, produk penelitian dan pengembangan ini sangat valid dan dapat digunakan sebagai media pembelajaran
\end{abstract}

\author{
Alamat Korespondensi: \\ Ian Rizky Maulana \\ Pendidikan Olahraga \\ Universitas Negeri Malang \\ Jalan Semarang 5 Malang \\ E-mail: ian.rizky.maulana@gmail.com
}

Era modernisasi atau globalisasi seperti saat ini sangat berpengaruh bagi berlangsungnya pendidikan. Perkembangan ilmu pengetahuan dan teknologi berkembang pesat sejalan dengan berkembangnya sumber daya manusia, begitu juga ilmu pengetahuan dan teknologi sangat memengaruhi perkembangan pendidikan (Massoud, Umar, Stockley, \& Noureldin, 2011). Kini, teknologi tidak dapat lepas dari kehidupan manusia. (Xavier \& Francis, 2017) mengungkapkan bahwa teknologi telah masuk ke dalam kehidupan manusia dan masyarakat yang menjadikannya aspek penting untuk kelangsungan hidup sehari-hari baik itu kehidupan sosial, pendidikan, profesional dan kehidupan agamanya. Temuan-temuan baru pada bidang pendidikan dikarenakan teknologi yang semakin maju. Teknologi dapat menambah daya guna asalkan dimanfaatkan dengan tepat (Dwiyogo, 2008). Dalam dunia pendidikan tidak dapat terlepas dari sentuhan teknologi (Purwaningtyas, Dwiyogo, \& Hariyadi, 2017). Hal ini terbukti semakin banyak penggunaan media berupa peralatan elektronik, seperti smartphone yang dipakai di dalam dunia pendidikan. Hal ini didukung pendapat dari (Clayton \& Murphy, 2016) bahwa smartphone adalah perangkat yang mayoritas dimiliki oleh peserta didik, pendidik perlu mempercepat cara memanfaatkan perangkat ini serta dapat digunakan secara positif dan produktif di kelas. 
Dalam dunia pendidikan, pemanfaatan teknologi memberikan kontribusi nyata. Pendidikan akan menyenangkan, kreatif, mudah, efisien, menarik, dan mudah dipahami oleh siswa. Pendidikan dimasa depan akan bersifat lunak, terbuka, dan dapat diakses oleh siapapun juga yang memerlukannya tanpa memandang gender, umur, dan latar belakang pendidikan sebelumnya (Poon, 2013). Dunia pendidikan dengan berbagai kemudahan dan dapat diakses setiap saat dapat dilakukan dengan memanfaatkan teknologi (Purwaningtyas et al., 2017). Seperti yang disampaikan (Dian, 2017) dukungan atau kontribusi teknologi informasi dalam teknologi pembelajaran mencakup aspek-aspek infrastruktur, informasi dan telekomunikasi, sumber daya manusia dan referensi atau produk telematik hukum sehingga mereka dapat berperan dalam mendidik masyarakat melalui pengembangan atau penggunaan sumber belajar. (Ngure, Nyakwara, Kimani, \& Mweru, 2014) juga mengatakan bahwa pemanfaatan media dalam pengajaran dapat memberikan akses pada gagasan baru seperti cara belajar, cara mengakses informasi yang sulit ditemukan, klarifikasi istilah atau konsep yang sulit dan bagaimana menyajikan informasi dengan menggunakan media pembelajaran yang berbeda. (Cakmak \& Tuzel, 2015) menambahkan bahwa media pembelajaran bertujuan untuk meningkatkan kemampuan individu tidak hanya membaca, mendengar, mengamati dan menganalisa, tetapi juga menciptakan media dalam berbagai bentuk.

Dengan memanfaatkan penggunaan multimedia, khususnya media pembelajaran autoplay dalam Pendidikan Jasmani, siswa pengalaman baru akan didapatkan siswa secara maksimal. Kesempatan siswa untuk mendapatkan materi pembelajaran yang lebih komunikatif dan menyenangkan akan lebih tersaji. Tidak tercurahkan kepada guru yang berbicara atau contoh gerakan dari guru yang tidak maksimal, pada akhirnya mendapatkan pemahaman dan pengetahuan kurang.

Teknologi informasi yang berkembang sangat pesat saat ini, khususnya perkembangan teknologi pendidikan turut mendorong berkembangnya konsep pembelajaran berbasis autoplay ini (Delialioğlu, 2012). Ciri pembelajaran pendidikan jasmani materi bola besar berbasis autoplay kapanpun, dimanapun dan menampilkan materi pembelajaran secara rinci dengan dilengkapi video pembelajaran dan juga memberi apapun kemudahannya telah menjadikan pembelajaran berbasis autoplay sangat tepat bagi perkembangan pendidikan anak di sekolah (Akkoyunlu \& Soylu, 2006). Hal inilah kenapa pembelajaran pendidikan jasmani materi bola besar berbasis autoplay masih sangat baik diterapkan di negara berkembang, seperti Indonesia karena dapat terkontrol secara konvensional (Purwaningtyas et al., 2017).

Hasil penelitian oleh (Walsh, 2013) mengemukakan bahwa anak yang diajarkan hanya dengan cara tradisional pencapaian belajarnya akan lebih rendah jika dibandingkan dengan pembelajaran dalam format pembelajaran audio visual. Temuan (Ruiz, Mintzer, \& Leipzig, 2006) juga mengemukakan ada pengaruh yang signifikan antara pemahaman siswa dengan belajar melalui audio visual terhadap prestasi belajar. Dari penelitian di atas dapat disimpulkan bahwa faktor pengajar atau guru, faktor pembelajar atau siswa dan faktor teknis merupakan faktor penting bagi kesuksesan anak yang diajarkan materi bola besar dalam pendidikan jasmani berbasis autoplay. Rekomendasi dari penelitian ini mungkin berguna untuk menginformasikan dan membimbing anak dalam hal pembelajaran Pendidikan Jasmani khususnya materi bola besar. Oleh karena itu, proses belajar mengajar menggunakan media autoplay sangat efektif apabila diterapkan di SMP yang membina anak usia $12-14$ tahun.

Siswa SMP memiliki karakteristik perkembangan yang pertumbuhan fisiknya telah matang, tubuh dan keseimbangan dapat dikontrol oleh siswa usia SMP (Zulkifli, 2006). Mereka telah dapat melompat dengan kaki secara bergantian, dapat menangkap bola dan telah berkembang koordinasi tangan dan mata untuk berlatih teknik dasar dalam sepakbola yang lebih kompleks. Selain itu, pada usia SMP perkembangan sosial anak yaitu mereka sudah dapat bersaing dengan teman seumuran, memiliki teman dekat, dan dapat bersosial dan mandiri (Hartinah, 2008). Siswa SMP tahap perkembangan emosinya telah dapat mengungkapkan perasaan terhadap orang lain, sudah dapat mengontrol emosi dan sudah dapat berpisah dengan orangtua dan belajar tentang right dan wrong (Hurlock, 2000). Siswa SMP memiliki perkembangan kecerdasan ditunjukkan dengan kemampuannya dalam melakukan seleksi, objek dikelompokkan, menyukai angka dan tulisan, meningkatnya vocabullary, banyak bicara (Yusuf \& Syamsu, 2006).

Cara belajar pada anak usia SMP, (Zhang \& Han, 2012) menyatakan bahwa setiap anak memiliki cara tersendiri dalam menginterpretasikan dan beradaptasi dengan lingkungannya (teori perkembangan kognitif). Menurutnya, setiap anak memiliki struktur kognitif yang disebut schemata yaitu sistem konsep yang ada dalam pikiran sebagai hasil pemahaman terhadap objek yang ada dalam lingkungannya. Pemahaman tentang objek tersebut berlangsung melalui proses asimilasi (menghubungkan objek dengan konsep yang sudah ada dalam pikiran) dan akomodasi (proses memanfaatkan konsep-konsep dalam pikiran untuk menafsirkan objek). Kedua proses tersebut jika berlangsung terus menerus akan membuat pengetahuan lama dan pengetahuan baru menjadi seimbang. Dengan cara seperti itu secara bertahap anak dapat membangun pengetahuan melalui interaksi dengan lingkungannya. Berdasarkan hal tersebut, maka perilaku belajar anak sangat dipengaruhi oleh aspek-aspek dari dalam dirinya dan lingkungannya. Kedua hal tersebut tidak mungkin dipisahkan karena sebenarnya proses belajar terjadi dalam konteks interaksi diri anak dengan lingkungannya.

Berdasarkan paparan di atas maka pembelajaran pendidikan jasmani materi bola besar berbasis autoplay menjadi menjadi model pembelajaran yang tepat untuk memberikan pengalaman real dalam latihan teknik dasar karena model pembelajaran tersebut menggabungkan proses pembelajaran konvensional ditambah dengan penyampaian materi menggunakan audio visual di autoplay. Dalam penerimaan informasi anak usia SMP visual gambar dan buka teks dapat lebih menarik siswa (Purwaningtyas et al., 2017). Namun, pembelajaran berbasis unggulan memungkinkan para guru untuk memenuhi kebutuhan 
anak-anak mereka. Siswa harus belajar materi dengan cara dan interaksi baru untuk memenuhi minat pribadi mereka sehingga keterampilan ini dapat ditransfer ke dunia nyata (Oliver \& Trigwell, 2005). Ini benar bahkan di bidang teknologi pembelajaran, dimana konsep relokasi, kolaborasi, dan upaya tim dunia nyata (kerja kelompok) ditingkatkan. Selain itu, anak-anak dapat menggunakan teknologi sebagai alat belajar di bawah bimbingan guru dan orangtua untuk memungkinkan mereka merancang, mengembangkan, dan mengevaluasi proses dan sumber daya untuk mempelajari teknologi, seperti praktisi setiap hari. Anda perlu belajar. Model pembelajaran mandiri tidak hanya alat pembelajaran, tetapi juga cara untuk menempatkan konten materi pembelajaran, terutama bola besar ke dalam praktik.

Untuk mengikuti pembelajaran Pendidikan Jasmani biasanya harus adu faktor-faktor yang mendorong siswa untuk terus bersemangat mengikuti pelajaran pendidikan jasmani. Salah satunya dengan media autoplay dalam penelitian ini yang juga dapat menstimulus semangat siswa karena tampilan dan juga contoh gerakan dalam video yang lain dari proses belajar mengajar sebelumnya. Tampilan dan video yang ada dalam autoplay pendidikan jasmani materi bola besar ini dapat membantu guru dalam hal visualisasi yang unik sehingga siswa dengan karakter masih kekanak-kanakan gemar melihat video pembelajaran pendidikan jasmani materi bola besar yang disediakan. Dalam tatap muka guru berperan untuk melihat serta memberi arahan gerakan pada anak selama proses pembelajaran karena materi telah disampaikan melalui media di autoplay. Karakteristik anak pada usia SMP dalam berlatih masih bersifat bermain (Yusuf \& Syamsu, 2006). Dengan mencampurkan bermain dan belajar maka anak akan memiliki pengalaman belajar yang dapat meningkatkan minat pada pembelajaran pendidikan jasmani, karena penampilan yang unik di dalam materi pembelajaran teori dan praktik yang dirancang sedemikian rupa menggunakan nada, animasi maupun gambar sehingga tidak mengakibatkan kebosanan selama proses penyampaian pembelajaran Pendidikan Jasmani materi bola besar berlangsung.

Menurut hasil analisis kebutuhan yang dilakukan kepada siswa SMP Negeri di kabupaten Lumajang sejumlah 155 siswa atau $100 \%$ menyatakan guru PJOK di sekolah tidak pernah menggunakan laptop dalam pembelajaran. 155 siswa atau $100 \%$ menyatakan penggunaan multimedia dalam pembelajaran akan membuat belajar menjadi lebih menyenangkan (tidak membosankan). 92 siswa atau 59,4\% mengalami kesulitan saat pembelajaran Pendidikan Jasmani materi bola besar. 114 siswa atau 73,5\% menyatakan penjelasan dan contoh dari guru tidak cukup untuk memahami materi bola besar dalam pendidikan jasmani. Sedangkan 155 siswa atau 100\% menyatakan guru Pendidikan Jasmani di sekolah tidak pernah menggunakan media (audio, visual, animasi) dalam pembelajaran khususnya bola besar. 155 siswa atau 100\% responden setuju dan dianggap perlu menggunakan multimedia (audio visual dan animasi) dalam pembelajaran Pendidikan Jasmani materi bola besar. Oleh sebab itu, 155 siswa atau 100\% sangat setuju apabila dikembangkan bahan ajar yang menggunakan audio, visual maupun animasi dalam pembelajaran pendidikan jasmani khususnya materi bola besar.

\section{METODE}

Penelitian ini termasuk ke dalam jenis Research \& Development (R\&D) yang bertujuan untuk menghasilkan sebuah produk melalui prosedur atau langkah-langkah tertentu. Model penelitian dan pengembangan bertujuan untuk menghasilkan produk berupa media pembelajaran bola besar berbasis autoplay media studio untuk SMP kelas VII. Penelitian pengembangan merupakan penelitian pengembangan produk tertentu sesuai dengan kebutuhan masyarakat saat ini. Model penelitian dan pengembangan produk menggunakan model prosedural yang berkesinambungan antara satu dengan lainnya serta mempunyai interkoreksi antara berbagai langkah yang harus ditempuh atau dikembangkan (Hadiansah, Widiyanti, \& Bangun, 2017). Dalam artikel ini, model penelitian dan pengembangan ini menggunakan model penelitian dan pengembangan yang diadaptasi dari (Lee \& Owens, 2017) yang menyimpulkan langkah-langkah tersebut, meliputi (1) analisis kebutuhan, (2) analisis awal dan akhir, (3) desain produk, (4) pengembangan produk, (5) pelaksanaan, dan (6) evaluasi produk.

Penelitian ini dilakukan menggunakan model pengembangan multimedia yang dikembangkan oleh Lee \& Owen. Model ini dipilih karena produk yang dihasilkan berupa multimedia interaktif berbasis autoplay, tahapan-tahapan model pengembangan multimedia ini, yaitu analisis, desain pengembangan, implementasi, dan evaluasi. Peneliti akan mengembangkan sebuah produk berupa bahan ajar berbentuk multimedia interaktif pembelajaran bola besar berbasis autoplay untuk SMP kelas VII. Dalam pembuatan produk tentunya harus divalidasi terlebih dahulu oleh ahli dalam bidangnya sebelum digunakan di lapangan sehingga produk telah tervalidasi dapat diujikan dalam kelompok kecil dan kelompok besar untuk mengetahui kekurangan dan kelebihan produk yang telah dihasilkan.

Instrumen pengumpulan data yang digunakan dalam pengembangan ini berupa angket untuk menjaring data dari subjek ahli, meliputi ahli pembelajaran Pendidikan Jasmani dan Kesehatan, ahli materi bola besar, dan ahli media. Bentuk angket setiap ahli berbeda untuk mengumpulkan data tentang evaluasi berupa masukan, komentar, dan saran dari para ahli. Selain itu, ada penyebaran angket untuk siswa saat uji coba kelompok kecil dan uji coba kelompok besar.

Teknik yang digunakan dalam penelitian ini adalah kualitatif dan kuantitatif. Teknik analisis kualitatif dapat digunakan untuk menganalisis pengumpulan data dan masukan ahli menggunakan pendekatan kualitatif untuk mengurangi makna data terhadap pengumpulan data, pilih dan fokus pada hal-hal penting untuk ditampilkan di bawah ini. Ketika analisis kuantitatif digunakan untuk memproses data dengan meningkatkan penelitian, gunakan analisis kuantitatif persentase untuk memproses data 
yang diperoleh dari hasil tes. Teknik analisis data yang digunakan dalam penelitian ini adalah teknik analisis berbasis persentase. Rumus yang digunakan untuk pengolahan data dengan teknik analisis data deskriptif dalam bentuk persentase yang digunakan untuk persentase pengumpulan data dalam analisis kebutuhan adalah dalam tes kelompok kecil dan tes kelompok besar. Menurut (Akbar, 2016) pengolahan data dapat menggunakan rumus sebagai berikut.

$$
V=\frac{T S e}{T S h} \times 100 \%
$$

Keterangan:

$$
\begin{array}{ll}
V & : \text { Validatas. } \\
\text { TSe } & \text { : Total Skor Empirik } \\
\text { TSh } & \text { : Total Skor Maksimal }
\end{array}
$$

Untuk mempermudah kesimpulan rumus diatas terhadap hasil persentasi tingkat kemenarikan produk pengembangan, ditetapkan kriteria penggolongan dapat dilihat pada tabel 1.

Tabel 1. Tabel Persentase Kelayakan Produk Penelitian dan Pengembangan

\begin{tabular}{ccl}
\hline No & Kriteria & \multicolumn{1}{c}{ Tingkat Validitas } \\
\hline 1 & $81,00-100,00 \%$ & Sangat Valid (dapat digunakan tanpa direvisi) \\
\hline 2 & $61,00-80,00 \%$ & Cukup Valid (dapat digunakan dengan direvisi kecil) \\
\hline 3 & $41,00-60,00 \%$ & Kurang Valid (disarankan tidak digunakan karena perlu revisi) \\
\hline 4 & $21,00-40,00 \%$ & Tidak Valid (tidak boleh digunakan) \\
\hline 5 & $00,00-20,00 \%$ & Sangat Tidak Valid (tidak boleh digunakan) \\
\hline
\end{tabular}

Sumber: (Akbar, 2016)

\section{HASIL}

\section{Analisis Kebutuhan}

Analisis kebutuhan ini digunakan sebagai langkah awal dalam penelitian pengembangan dengan melakukan observasi dan menyebarkan kuesioner sehingga diperoleh suatu masalah atau kesenjangan antara kondisi nyata dan kondisi yang diinginkan yang menjadi kebutuhan di lapangan. Analisis kebutuhan lapangan dilakukan pada Januari 2018 dengan penyebaran kuesioner kepada 155 siswa SMP Negeri di kabupaten Lumajang. Menurut hasil observasi awal melalui penyebaran angket kepada 155 siswa SMP Negeri di kabupaten Lumajang, didapatkan bahwa dalam pembelajaran belum menerapkan pembelajaran pendidikan jasmani materi bola besar berbasis autoplay media studio serta pemanfaatan media berbasis teknologi. Oleh sebab itu, perlu diterapkannya pembelajaran Pendidikan Jasmani materi bola besar berbasis autoplay media studio serta pemanfaatan media pembelajaran berbasis teknologi dengan tujuan meningkatkan minat siswa terhadap Pendidikan Jasmani khususnya materi bola besar.

\section{Analisis Ahli Validasi Pembelajaran}

Dari validasi ahli pembelajaran didapatkan hasil yaitu tentang kejelasan materi yang disajikan dalam pembelajaran Pendidikan Jasmani materi bola besar berbasis autoplay media studio sebesar 73,44\% cukup valid, tentang ketepatan materi yang disajikan dalam pembelajaran Pendidikan Jasmani materi bola besar berbasis autoplay media studio mendapat persentase sebesar $75,00 \%$ cukup valid, tentang kesesuaian materi yang disajikan dalam pembelajaran Pendidikan Jasmani materi bola besar berbasis autoplay media studio sebesar 75,00\% cukup valid, tentang kemudahan materi yang disajikan dalam pembelajaran Pendidikan Jasmani materi bola besar berbasis autoplay media studio sebesar 75,00\% cukup valid, tentang kemenarikan materi yang disajikan dalam pembelajaran Pendidikan Jasmani materi bola besar berbasis autoplay media studio sebesar 82,14\% sangat valid. Rata-rata keseluruhan dari validasi ahli pembelajaran Pendidikan Jasmani diperoleh persentase 76,12\% cukup valid, cukup efektif, cukup tuntas, dapat digunakan, namun perlu perbaikan kecil. Berdasarkan hasil analisis data maka produk pengembangan pembelajaran Pendidikan Jasmani materi bola besar berbasis autoplay media studio ini dapat dilanjutkan ke tahap uji coba kelompok dengan revisi kecil.

\section{Analisis Validasi Ahli Materi Bola Besar}

Dari validasi ahli materi didapatkan hasil yaitu tentang kejelasan materi yang disajikan dalam pembelajaran Pendidikan Jasmani materi bola besar berbasis autoplay media studio sebesar 93,75\% sangat valid, tentang ketepatan materi yang disajikan dalam pembelajaran Pendidikan Jasmani materi bola besar berbasis autoplay media studio mendapat persentase sebesar 91,67\% 
sangat valid, tentang kesesuaian materi yang disajikan dalam pembelajaran Pendidikan Jasmani materi bola besar berbasis autoplay media studio sebesar 91,67\% sangat valid, tentang kemudahan materi yang disajikan dalam pembelajaran pendidikan jasmani materi bola besar berbasis autoplay media studio sebesar 100\% sangat valid, tentang kemenarikan materi yang disajikan dalam pembelajaran pendidikan jasmani materi bola besar berbasis autoplay media studio sebesar 96,43\% sangat valid. Rata-rata keseluruhan dari validasi ahli materi diperoleh persentase 94,70\% sangat valid. Berdasarkan hasil analisis data maka produk pengembangan pembelajaran Pendidikan Jasmani materi bola besar berbasis autoplay media studio ini dapat dilanjutkan ke tahap uji coba kelompok.

\section{Analisis Validisi Ahli Media}

Dari validasi ahli media didapatkan hasil yaitu penilaian pada teks memiliki persentase sebesar 96,88\% sangat valid, gambar/foto diperoleh persentase sebesar $100 \%$ sangat valid, audio suara diperoleh persentase $91,67 \%$ sangat valid, video diperoleh persentase sebesar 83,33\% sangat valid, dan desain atau tampilan diperoleh persentase sebesar $100 \%$. Rata-rata keseluruhan dari validasi ahli media diperoleh persentase 94,38\% sangat valid. Berdasarkan hasil analisis data maka produk pengembangan pembelajaran pendidikan jasmani materi bola besar berbasis autoplay media studio ini dapat dilanjutkan ke tahap uji coba kelompok.

\section{Analisis Data Uji Kelompok Kecil}

Uji coba kelompok kecil dilaksanakan pada bulan April 2019. Uji coba kelompok kecil ini digunakan untuk menghasilkan saran revisi lebih lanjut. Uji coba kelompok kecil dilakukan dengan penyebaran kuesioner kepada 20 siswa SMP Negeri 5 Lumajang. Hasil dari uji coba kelompok kecil didapat persentase rata-rata sebesar 94,63\% sangat valid. Sesuai dengan tabel kriteria persentase hasil pengolahan data hasil tersebut telah memenuhi kelayakan sehingga produk pengembangan media pembelajaran pendidikan jasmani materi bola besar berbasis autoplay media studio dapat dinyatakan sangat valid dan layak digunakan tanpa revisi serta dapat dilanjutkan pada tahap selanjutnya yaitu melakukan ke uji coba kelompok besar.

\section{Analisis Data Uji Kelompok Besar}

Uji coba kelompok besar dilaksanakan pada bulan April 2019. Uji coba kelompok besar yang merupakan tahap akhir dalam evaluasi formatif ini dilakukan dengan tujuan untuk mengindentifikasi kekurangan desain pembelajaran yang akan digunakan pada kondisi sebenarnya. Uji coba kelompok besar dilakukan dengan penyebaran kuesioner kepada 90 siswa SMP Negeri 1 Lumajang, SMP Negeri 1 Sukodono dan SMP Negeri 5 Lumajang. Hasil dari uji coba kelompok besar didapat persentase rata-rata sebesar 90,02\% sangat valid. Kriteria tersebut telah memenuhi kelayakan, sehingga produk pengembangan media pembelajaran pendidikan jasmani materi bola besar berbasis autoplay media studio dinyatakan sangat valid, dengan hasil 75,01 $100,00 \%$ termasuk dalam kategori sangat valid serta dapat digunakan tanpa revisi, sehingga dapat disimpulkan bahwa produk pengembangan pembelajaran media pembelajaran Pendidikan Jasmani materi bola besar berbasis autoplay media studio yang sudah di uji coba dapat digunakan sebagai produk pembelajaran.

\section{Evaluasi/Revisi Produk}

Tahap evaluasi, pengembang melakukan evaluasi terhadap produk multimedia interaktif. Evaluasi yang dilakukan berorientasi pada kevalidan multimedia yang dikembangkan melalui validasi ahli media, ahli materi, ahli pembelajaran serta hasil uji coba produk. Tahap evaluasi ini berkaitan dengan tahap sebelumnya, yaitu tahap implementasi. Tahap evaluasi dilakukan setelah masing-masing serangkaian kegiatan implementasi (validasi ahli dan uji coba produk) dilakukan. Tahap evaluasi dilakukan berdasarkan hasil validasi ahli dan uji coba produk. Adapun revisi yang dilakukan disajikan dalam tabel 2.

\section{PEMBAHASAN}

Produk pengembangan media pembelajaran yang dikembangkan ini menggunakan model Lee \& Owens dengan tujuan utama untuk menciptakan dan memfasilitasi proses terjadinya belajar Pendidikan Jasmani dimana dan kapan saja. Media pembelajaran Pendidikan Jasmani berbasis autoplay media studio juga membantu guru dalam proses belajar mengajar. Guru dapat menunjukkan contoh yang nyata, jelas dan konkret untuk setiap gerakan-gerakan kepada siswa. Dalam media pembelajaran berbasis autoplay media studio juga memberikan pengetahuan baik itu ranah kognitif, afektif, psikomotor dan juga dapat membuat pembelajaran Pendidikan Jasmani lebih menyenangkan.

(Bloom, 1956) menyatakan bahwa tujuan dari pendidikan dibagi menjadi afektif, kognitif, dan psikomotor. Selanjutnya menurut (Mufdalifah, 2014) tujuan pembelajaran merupakan bagian penting pada setiap proses pembelajaran karena untuk mengarahkan dan menuntun kegiatan belajar yang ingin dicapai pada setiap akhir pelajaran. Tujuan utama dari produk pengembangan pembelajaran berbasis blended learning pada matakuliah tenis lapangan ini adalah dapat menjadi metode baru dan alternatif sebagai sumber belajar yang memberikan pengetahuan baik itu ranah kognitif, afektif, dan psikomotor. 
Tabel 2. Revisi Produk

\begin{tabular}{clll}
\hline No & \multicolumn{1}{c}{ Saran atau Revisi } & \multicolumn{1}{c}{ Sebelum Revisi } & \multicolumn{1}{c}{ Sesudah Revisi } \\
\hline 1 & Font terlalu besar & Font dalam buku QR Code terlalu besar & Font disesuaikan dan tidak terlalu besar \\
2 & Sebaiknya buku SMP \pm 200 halaman & Jumlah halaman hanya 84 & $\begin{array}{l}\text { Jumlah halaman buku QR Code 180 } \\
\text { halaman }\end{array}$ \\
& & & Gambar animasi dalam buku QR code \\
3 & $\begin{array}{l}\text { Gambar animasi dalam buku QR code } \\
\text { disesuaikan dengan siswa SMP }\end{array}$ & Gambar animasi kekanak-kanakan & sudah disesuaikan dengan siswa SMP \\
4 & $\begin{array}{l}\text { Tidak ada kejelasan kerangka isi } \\
\text { pembelajaran bagi siswa }\end{array}$ & $\begin{array}{l}\text { Tidak ada kejelasan kerangka isi } \\
\text { pembelajaran bagi siswa }\end{array}$ & $\begin{array}{l}\text { Sudah ditambahkan kerangka isi } \\
\text { pembelajaran bagi siswa }\end{array}$ \\
& $\begin{array}{l}\text { Tambahkan kejelasan tujuan (kognitif, } \\
\text { afektif, dan psikomotor) dalam } \\
\text { pembelajaran pendidikan jasmani materi } \\
\text { bola besar }\end{array}$ & $\begin{array}{l}\text { Tidak ada kejelasan tujuan (kognitif, } \\
\text { afektif, dan psikomotor) dalam } \\
\text { pembelajaran pendidikan jasmani } \\
\text { materi bola besar }\end{array}$ & $\begin{array}{l}\text { Sudah ditambahkan kejelasan tujuan } \\
\text { (kognitif, afektif dan psikomotor) dalam } \\
\text { pembelajaran Pendidikan Jasmani materi } \\
\text { bola besar }\end{array}$ \\
$\begin{array}{l}\text { Tambahkan video pengembangan materi } \\
\text { melalui permainan dari yang sederhana } \\
\text { sampai ke yang kompleks dalam } \\
\text { permainan bola basket }\end{array}$ & $\begin{array}{l}\text { Tidak ada video pengembangan materi } \\
\text { melalui permainan dari yang sederhana } \\
\text { sampai ke yang kompleks dalam } \\
\text { permainan bola basket }\end{array}$ & $\begin{array}{l}\text { Sudah ditambahkan video pengembangan } \\
\text { materi melalui permainan dari yang } \\
\text { sederhana sampai ke yang kompleks/sulit } \\
\text { dalam permainan bola basket }\end{array}$ \\
$\begin{array}{l}\text { Tambahkan video pengembangan materi } \\
\text { melalui permainan dari yang sederhana } \\
\text { sampai ke yang kompleks dalam } \\
\text { permainan bola voli }\end{array}$ & $\begin{array}{l}\text { Tidak ada video pengembangan materi } \\
\text { melalui permainan dari yang sederhana } \\
\text { sampai ke yang kompleks dalam } \\
\text { permainan bola voli }\end{array}$ & $\begin{array}{l}\text { Sudah ditambahkan video pengembangan } \\
\text { materi melalui permainan dari yang } \\
\text { sederhana sampai ke yang kompleks dalam } \\
\text { permainan bola voli }\end{array}$ \\
\hline
\end{tabular}

Dalam tahap penelitian dan pengembangan ini tidak lepas dari penilaian ahli-ahli dibidangnya. Peneliti melakukan validasi terhadap tiga orang ahli, yaitu ahli media, ahli materi, dan ahli pembelajaran. Validasi pertama yaitu ahli media dengan aspek yang dinilai menggunakan 27 butir pertanyaan yang dibagi menjadi lima aspek, meliputi (1) teks, (2) gambar/foto, (3) Audio, (4) video, dan (5) desain/tampilan. Saran yang telah disebar dan direkap sesuai dengan masukan dan saran yang diberikan oleh ahli media.

Validasi ahli materi bola besar (dosen S3 FIK Universitas Negeri Malang) dan ahli pembelajaran Pendidikan Jasmani (Dosen S3 FIK Universitas Negeri Malang) dengan rincian 31 pernyataan dan pertanyaan untuk validasi ahli materi bola besar dan 31 pernyataan dan pertanyaan untuk validasi ahli pembelajaran Pendidikan Jasmani. Pernyataan dibagi menjadi lima komponen, yaitu (1) kejelasan, (2) ketepatan, (3) kesesuaian, (4) kemudahan, dan (5) kemenarikan. Secara keseluruhan, masukan dan saran dari ahli materi bola besar maupun ahli pembelajaran Pendidikan Jasmani telah dilakukan perbaikan dan revisi dan kedua validator mengatak layak untuk digunakan.

Setelah melakukan revisi terhadap masukan dan saran yang diberikan oleh ahli media, materi dan pembelajaran, selanjutnya peneliti melakukan ujicoba kelompok kecil dan kelompok besar. Ujicoba kelompok kecil dan kelompok besar menggunakan angket dengan jumlah butir soal sebanyak 17 pernyataan untuk menilai media berbasis autoplay media studio maupun buku penunjang scan $Q R$ code. Selanjutnya, peneliti melakukan pengolahan data dengan cara merekap, menjumlahkan dan menghitung persentasenya dari setiap komponen dikonversikan ke dalam bentuk tabel, dan masukan maupun saran yang secara keseluruhan sudah direvisi sesuai dengan hasil dari uji coba kelompok.

Produk pembelajaran pendidikan jasmani materi bola besar berbasis autoplay media studio memiliki kelebihan yaitu pembahasan materi yang dikemas lebih menarik dan menyenangkan. Produk tersebut dilengkapi dengan video-video pembelajaran yang dapat menggantikan guru memberikan contoh ketika guru tersebut tidak dapat memberikan contoh gerakan dengan baik. Setiap materi yang ada dalam produk autoplay media studio tersebut dilengkapi dengan video penunjang membuat siswa tidak bosan dalam proses pembelajaran Pendidikan Jasmani.

Produk pembelajaran Pendidikan Jasmani materi bola besar berbasis autoplay media studio yang peneliti kembangkan juga menghasilkan produk berupa modul cetak atau buku penunjang scan $Q R$ code. Modul cetak tersebut berisi semua materi yang ada di dalam aplikasi autoplay media studio. Kelebihan dari modul cetak tersebut adalah dilengkapi dengan scan QR code yang dapat memudahkan siswa melihat video dalam smartphonenya. Siswa hanya memindai kode batang yang ada dalam buku maka video secara otomatis akan muncul dan play didalam smartphone android. Kelebihan tersebut sesuai dengan tujuan peneliti untuk membuat pembelajaran Pendidikan Jasmani yang menyenangkan, mudah, bervariatif, kapan dan dimana saja dapat belajar gerak. 


\section{SIMPULAN}

Pengembangan pembelajaran Pendidikan Jasmani materi bola besar berbasis autoplay media studio ini dapat membantu siswa lebih maksimal dalam proses pembelajaran Pendidikan Jasmani, khususnya materi bola besar dan membantu memudahkan tugas pengajar. Produk yang dihasilkan merupakan produk yang ditujukan untuk siswa kelas VII SMP/MTs khususnya di kabupaten Lumajang, tetapi tidak menutup kemungkinan produk ini bisa digunakan oleh SMP/MTs di kabupaten atau kota lain.

Saran-saran peneliti dalam pengembangan penelitian ini menuju ke arah lebih lanjut, sebagai berikut. Pertama, subjek penelitian diharapkan lebih luas, baik dari jumlah subjek dan atau tidak hanya di siswa kelas VII SMP/MTs di kabupaten Lumajang, tetapi di sekolah lain yang memiliki sarana teknologi memadai. Kedua, produk pengembangan bukan hanya pada materi bola besar, tetapi pada semua materi yang disajikan pada pembelajaran pendidikan jasmani. Ketiga, produk pengembangan bukan hanya untuk siswa SMP/MTs kelas VII, tetapi pada semua kelas dan semua jenjang mulai SD sampai SMA untuk pembelajaran Pendidikan Jasmani. Keempat, pengembangan aplikasi autoplay media studio dan modul cetak atau buku penunjang scan $Q R$ code bisa ditambahkan fitur lagi, seperti quiz yang bisa langsung dikerjakan pada smartphone. Kelima, pengembangan aplikasi autoplay media studio dan modul cetak atau buku penunjang scan QR code bisa ditambahkan fitur add video jadi siswa maupun guru dapat berkontribusi untuk menambahkan video pembelajaran Pendidikan Jasmani. Demikian saran terhadap pengembangan, pemanfaatan, maupun diseminasi produk terhadap pengembangan media pembelajaran Pendidikan Jasmani materi bola besar berbasis autoplay media studio untuk kelas VII SMP/MTs dan modul cetak atau buku penunjang scan QR code.

\section{DAFTAR RUJUKAN}

Akbar, S. (2016). Instrumen Perangkat Pembelajaran. Bandung: Remaja Rosdakarya.

Akkoyunlu, B., \& Soylu, M. Y. (2006). A Study on Students' Views on Blended Learning Environment. Turkish Online Journal of Distance Education, 7(3), 43-56.

Bloom, B. S. (1956). Taxonomy of Educational Objectives: The Classification of Educational Goals, Handbook I Cognitive Domain. New York: Longmans, Green and Co.

Cakmak, E., \& Tuzel, S. (2015). Debates about the Future of Media Literacy in Turkey. Journal of Media Literacy Education, $7(3), 1-15$.

Clayton, K., \& Murphy, A. (2016). Smartphone Apps in Education: Students Create Videos to Teach Smartphone Use as Tool for Learning. Journal of Media Literacy Education, 8(2), 99-109.

Delialioğlu, Ö. (2012). Student Engagement in Blended Learning Environments with Lecture-Based and Problem-Based Instructional Approaches. Educational Technology and Society, 15(3), 310-322.

Dian, R. (2017). Teknologi Informasi dan Komunikasi (TIK) dan Kompetensi Teknologi Pembelajaran untuk Pengajaran yang Berkualitas. Jurnal Teknologi Pendidikan dan Pembelajaran, 2(1), 234-254.

Dwiyogo, W. D. (2008). Aplikasi Teknologi Pembelajaran Media Pembelajaran Penjas \& Olahraga. Malang: FIP UM.

Hadiansah, E. N., Widiyanti, \& Bangun, D. (2017). Uji Banding Rencana Pelaksanaan Pembelajaran Berbasis Saintifik dengan Model Pembelajaran Problem Based Learning dan Model Pembelajaran Langsung pada Mata Pelajaran Teknik Pemesinan. Jurnal Teknik Mesin, 25(1), 51-58.

Hartinah, S. (2008). Psikologi Perkembangan. Bandung: Refika Aditama.

Hurlock, E. (2000). Psikologi Perkembangan: Suatu Pendekatan Sepanjang Rentang Kehidupan. Jakarta: Erlangga.

Lee, W. W., \& Owens, D. L. (2017). Multimedia-Based Instructional Design: Computer-Based Training, Web- Based Training, and Distance Learning. Turkish Online Journal of Distance Education-TOJDE, 5(2), 90-93.

Massoud, A., Umar, I., Stockley, D., \& Noureldin, A. (2011). Using Blended Learning to Foster Education in a Contemporary Classroom. Transformative Dialogues: Teaching \& Learning Journal, 5(2), 1-11.

Mufdalifah, M. (2014). Personalized Learning dan Multimedia Berbasis Komputer Masih Perlukah Guru? (Jurnal Inovasi dan Teknologi Pembelajaran) Kajian dan Riset dalam Teknologi Pembelajaran, 1(1), 50-57.

Ngure, G., Nyakwara, B., Kimani, E., \& Mweru, M. (2014). Utilization of Instructional Media for Quality Training in PrePrimary School Teacher Training Colleges in Nairobi. Research Journal of Education, 2(7), 1-22.

Oliver, M., \& Trigwell, K. (2005). Can "Blended Learning” Be Redeemed? E-Learning, 2(1), 17. https://doi.org/10.2304/elea.2005.2.1.2

Poon, J. (2013). Blended Learning: An Institutional Approach for Enhancing Students' Learning Experiences. MERLOT Journal of Online Learning and Teaching, 9(2), 271-289.

Purwaningtyas, P., Dwiyogo, W. D., \& Hariyadi, I. (2017). Pengembangan Modul Elektronik Mata Pelajaran Pendidikan Jasmani, Olahraga, dan Kesehatan Kelas XI Berbasis Online dengan Program Edmodo. Jurnal Pendidikan: Teori, Penelitian, dan Pengembangan, 2(1), 121-129.

Ruiz, J. G., Mintzer, M. J., \& Leipzig, R. M. (2006). The Impact of E-Learning in Medical Education. IT in Medical Education, 81(3), 207-212. https://doi.org/10.1097/00001888-200603000-00002 
Walsh, M. (2013). Boys and Blended Learning: Achievement and Online Participation in Physical Education. Nihon Ronen Igakkai Zasshi. Japanese Journal of Geriatrics, 51(1),

Xavier, F., \& Francis, M. (2017). Use of Multimedia ( ICT ) as a Educational Tool in High School Education-A Study. Amity Journal of Media \& Communication Studies, 7(1), 31-37.

Yusuf, L., \& Syamsu, H. (2006). Psikologi Perkembangan Anak. Bandung: Remaja Rosdakarya.

Zhang, W., \& Han, C. (2012). A Case Study of the Application of a Blended Learning Approach to Web-based College English Teaching Platform in a Medical University in Eastern China. Theory and Practice in Language Studies, 2(9), 1961-1970. https://doi.org/10.4304/tpls.2.9.1961-1970

Zulkifli, L. (2006). Psikologi Perkembangan. Bandung: Remaja Karya. 